DEPARTMENT OF THE INTERIOR

\author{
U.S. GEOLOGICAL SURVEY
}

Earthquake-Induced Liquefaction Features in the Coastal South Carolina Region

by

Stephen F. Obermeier ${ }^{1}$, Robert E. Weems ${ }^{1}$, and Robert B. Jacobson ${ }^{1}$

Open-File Report 87-504

This report is preliminary and has not been reviewed for conformity with U.S. Geological Survey editorial standards.

IU.S. Geological Survey Reston, Virginia 
Earthquake-Induced Liquefaction Features in the Coastal South Carolina Region

I Introduction

II Earthquake-Induced Liquefaction Features

a. Geologic Setting

b. Types of Features

c. Confidence in Interpretation of Origin

III Ages of Craters

IV Holocene Earthquake Shaking

a. Methodology

b. Shaking Intensity

$\checkmark \quad$ Conclusions

VI References 


\title{
Earthquake-Induced Liquefaction Features in the Coastal South Carolina Region
}

\author{
Stephen F. Obermeier, Robert E. Weems, and Robert B. Jacobson \\ U.S. Geological Survey \\ National Center \\ Reston, Virginia 22092
}

Abstract

Features interpreted to be earthquake-induced sand blows of Holocene age have been discovered throughout much of the coastal region in South Carolina and in the southeastern extremity of North Carolina. Nearly all these sand blows presently are manifested as filled craters.

Interpretation of an earthquake origin for the craters is based on independent lines of evidence: (1) the filled craters have a morphology consistent with historical descriptions and photographs of sand blows produced by the Charleston, South Carolina earthquake of 1886; (2) the filled craters occur near or along the crests of Pleistocene beach ridges, which is a setting that corresponds with the geologic-topographic setting of the most abundant craters produced by the 1886 earthquake; (3) filled craters are especially abundant at sites reported in 1886; and (4), the filled craters have sedimentary relations that are consistent only with a suddenly applied, strong, short-lived, upward-directed hydraulic force which, on the topographically high beach ridge crests could reasonably have been produced only by earthquake-induced liquefaction.

The craters generally formed in episodes long-separated in time. Radiocarbon ages show that at least three prehistoric, liquefaction-inducing earthquakes have taken place within the past 7200 years near Charleston. Ages of some craters far from Charleston differ from ages near Charleston. Insufficient data have been collected to determine if all crater ages far from Charleston differ from ages near Charleston. 
Both the diameter and relative abundance of pre-1886 craters are greater in the vicinity of Charleston (particularly in the 1886 meisoseismal zone) than elsewhere along the coastal regions of South Carolina and southeastern North Carolina, although the susceptibility of the widespread beach deposit sites to earthquake-induced liquefaction is approximately the same throughout this area. These data indicate that, in this coastal region, the strongest earthquake shaking during the Holocene has taken place repeatedly near Charleston.

\section{INTRODUCTION}

The strongest historic earthquake in the southeastern United States took place in 1886 near Charleston, South Carolina. The meizoseismal zone (encompassing Modified Mercalli intensity-X effects) was about $35 \mathrm{~km}$ wide and $50 \mathrm{~km}$ long (Bollinger, 1977), and the estimated body-wave magnitude $\left(\mathrm{m}_{\mathrm{b}}\right)$ was between 6.6 and 7.1 (Nuttli, 1983). The potential for a future earthquake with the strength of the 1886 earthquake is a major concern in engineering design in the Southeast. The concern is reinforced by a 300-year historical record of continuing weak seismic activity near Charleston. The source of the earthquakes in the Charleston area remains unidentified, and seismotectonic hypotheses are widely disparate despite many geologic, geophysical, and seismic studies during the past decade. No faults or fault systems have been identified that fully explain the large 1886 Charleston earthquake or the other smaller, historic earthquakes which have occurred throughout much of South Carolina (Hays and Gori, 1983; Dewey, 1985; Science News, 1986). Because direct evidence of seismotectonic conditions is lacking and because the historic earthquake record is too limited to provide a dependable basis for estimating the frequency of moderate to strong earthquakes, we undertook a 
search for pre-1886 sand blows. Liquefaction-induced features, particularly sand blows, were a commonplace effect of the 1886 earthquake within the meizoseismal zone, causing us to first search that area. The initial discovery of pre-1886 sand blows was reported by Gohn and others (1984) and Obermeier and others (1985). The study was next extended throughout much of coastal South Carolina (Obermeier and others, 1986) and more recently into southeastern North Carolina.

Current results of the search are illustrated on Figure 1. Figure 1 shows (1) the approximate boundary of the 1886 Charleston earthquake meizoseismal zone, (2) areas conspicuous in 1886 for development of sand blows (described as "craterlets" by Dutton, 1889), and (3) the sites of pre1886 sand blows that we have discovered. The unshaded part of Figure 1 encompasses the principal area searched for sand blows; in this area, the sediments are predominantly of marine origin. Fluvial deposits were searched only locally along the Edisto River.

None of the pre-1886 sand blows have any expression on the ground surface that is discernible by on-site examination or on airphotos. The sand blows are seen only where exposed in walls of excavations at least $1.5 \mathrm{~m}$ in depth; generally, sand-blow exposures have been found in drainage ditches and borrow pits. At most sites shown on Figure 1 , at least three or four sand blows are exposed within a few hundred meters of one another. The following section focuses on the geologic setting in which these sand blows are found and on criteria for interpreting their earthquake origin.

\section{EARTHQUAKE-INDUCED LIQUEFACTION FEATURES}

\section{Earthquake Criteria}

Identification of an earthquake origin for the features we have observed 
depends primarily on eliminating (non-earthquake) artesian springs as an alternate mechanism. Other mechanisms that must be eliminated include liquefaction induced by ocean wave pounding, ground disruption by trees and landslides, compaction-induced dewatering, and physical and chemical weathering.

Geologic criteria we have developed for interpreting an earthquake origin for liquefaction features generally consist of four elements:

1. The features must have sedimentary characteristics that are consistent with an earthquake-induced liquefaction origin: that is, there is evidence of (a) an upward directed, strong hydraulic force that was (b) suddenly applied and (c) was of short duration.

2. The features have sedimentary characteristics that are consistent with historically-documented observations of earthquake-induced liquefaction processes.

3. The features are in groundwater settings where a suddenly applied, strong hydraulic force of short duration could not be reasonably expected except from earthquake-induced liquefaction. In particular, these settings must be extremely unlikely sites for artesian flowing springs.

4. Similar features must occur at multiple sites (within a few kilometers of one another), in similar geologic and groundwater settings. Where evidence of age is present, it should support the interpretation that the features formed in one or more discrete, short episodes that individually affected a large area and that were separated by long time periods during which no such features formed.

As fewer of these criteria are satisfied, the confidence in an earthquake origin generally diminishes. 


\section{GEOLOGIC SETTING}

In South Carolina, the coastal region is known locally as the "low country" because it has low local relief (1 to $3 \mathrm{~m}$ ) and low elevation (0 to $30 \mathrm{~m}$ ) and because vast expanses of swamp and marshland are under water much of the year. Most of the Carolina low country is covered by a 5- to 10-m-thick blanket of unconsolidated Quaternary marine and fluvial deposits, which lies on semilithified Tertiary sediments (McCartan and others, 1984). The Quaternary sediments primarily occur as a series of six well-defined, temporally discrete, interglacial beaches and associated back-barrier and shelf deposits that form belts subparallel to the present shoreline. The oldest beach deposits are farthest inland and at the highest altitudes; younger beach deposits are progressively closer to the ocean and at lower altitudes.

Figure 1 shows the approximate inland limits of the marine-related deposits (beach, shelf, and open-sound back barrier) designated as Q3 by (McCartan and others, 1984). Q3 deposits are about 200,000 to 240,000 years old (Szabo, 1985) and are present about 20 to $40 \mathrm{~km}$ inland from the modern coast. The part of Figure 1 containing units Q1, Q2, and Q3 of McCartan and others (1984) is shown without shading. The search for sand blows was generally restricted to these units because older deposits have such a low susceptibility to liquefaction (due to weathering and deep ground water) that the likelihood of forming sand blows during the Holocene and late Pleistocene has been extremely low.

The geologic setting most frequently associated with recognizeable earthquake-induced liquefaction features is the crest or flank of a Pleistocene beach ridge, where a thin cover of clay-bearing sand or humaterich soil overlies well-sorted, clean sand (i.e., containing no silt or 
clay). According to first hand observations of effects of the 1886 earthquake by Earl Sloan, "these craterlets are found in greatest abundance in belts parallel with (beach) ridges and along their anticlines" (Peters and Herrmann, 1986). A schematic cross-section through a typical low-country beach ridge, such as the ridges described by Sloan, is shown in Figure 2. To a much lesser extent, sand blows have been found in fluvial and back-barrier sediments.

\section{Types of Features}

At the great majority of sites on Figure 1, we observed the "craterlet" (or crater) type of sand blow, which was the type most abundantly produced by the 1886 earthquake. At a small number of sites, there is evidence for a second type of sand blow, in which the earthquake-induced features formed as deposits vented to the surface, leaving a relict sand mound. At a few sites, there is evidence for earthquake-induced oscillating ground movement on a liquefied stratum and for earthquake-induced lateral spreads (landslides of great lateral extent which formed on nearly level ground far from any scarps downsilope or upslope).

Sand blows--Only the crater type of sand blow is discussed because of the abundance of this type and because of the difficulty generally attendant in attributing an earthquake origin to the vented-sand-mound type of feature.

Almost all of the pre-1886 craters had an original morphology and size comparable to the 1886 craters described by Dutton (1889); however, today the craters are filled with sediment. All filled sand blow craters share many common sedimentary structures and sequences in fill sedimentation, which are illustrated in Figure 3. The figure shows a soil horizon cut by an irregular crater, which is filled with stratified to massive (nonstratified) and graded sediments; five layers (identified on the figure) are characteristically present. Materials within the craters are sand and clasts from the $\mathrm{Bh}$ 
(humate-rich B horizon), B-C, and C horizons, and sand from depths much below the exposed C horizon. In a pre-1886 filled crater, the Bh horizon that developed on the in-filled sediment generally is much thinner than the Bh horizon of the laterally adjacent, undisturbed soil. With increasing age, the Bh horizon on the filled crater becomes thicker, more clay rich, and has better developed soil structure.

Interpreted phases in the formation of the filled sand-blow craters include the following: (1) after earthquake-induced liquefaction at depth, a large hole is excavated at the surface by the violent upward discharge of the liquefied mixture of sand and water; (2) accumulation of a sand rim around the hole by continued expulsion of liquefied sand and water after the violent discharge; (3) churning of sand, soil clasts, and water in the lower part of the bowl, followed by settling of the larger clasts and formation of the graded-fill sequence; and (4) filling of the crater from adjacent surface materials to form the thin stratified-fill sequence, during the weeks to years after the eruption. In the craters predating the 1886 eathquake, the sand blanket ejected from the crater is indistinguishable in the field from the surface and near-surface (A, E, and $B h)$ soil horizons, because the blanket has been incorporated into these soil horizons.

We infer that the craters were formed by a short-lived process because of the presence of friable clasts of Bh- and C-horizon soil in the graded zone, and because of the very sharp boundary between the graded and layered zones (i.e., the contact between layers 3 and 4 ). We interpret that the force was strong and upward directed because many of the large clasts in layer 1 have clearly been rounded by tumbling in a fluidized bed. Where multiple craters occur along the topographically highest part of a beach ridge, and where multiple craters appear to have formed at the same time (on the basis of 
similar soil profiles or similar radiocarbon dates), then all four geologic criteria are satisfied for interpreting an earthquake origin. This interpretation of origin is strongly reinforced by historical accounts of the general morphology and geologic setting where the craters formed, and by our discovery of craters where they were reported by first-hand accounts (Peters and Herrmann, 1986) to be plentiful in 1886 (at sites HW and ARP on Fig. 1). Reverse shears--Along the flanks of some Pleistocene beaches, reverse shears in association with liquefaction features also were probably formed by earthquakes. The shears generally occur near the crests and on ground sloping less than 1 percent. Shear displacements commonly range from 1 to $4 \mathrm{~cm}$. These slopes are so gentle and the possibility of high artesian pressures is so remote that gravity-induced slumping is virtually impossible. Reverse shears of earthquake origin have also been found on level ground. At one site (site RRR on Fig. 1), for example, reverse shears dipping in opposite directions formed about $10 \mathrm{~m}$ apart in the stratum that liquefied during shaking, and sand blows with vents traceable to this liquefied stratum formed between the shears; the only possible mechanism that could have formed the opposite dipping shears was alternating directions of ground motion on the liquefied stratum.

Reverse shears can occur also as isolated features, but they are generally found in association with sand blows. In many filled craters there is a reverse shear near the edge of the crater. The shear is invariably located on the downslope side of the crater, and the shear cuts otherwise undisturbed soil horizons and underlying sediments. The shear formed prior to venting because the vent is not cut by the shear. At some sites, the shears along crater edges could have formed only in response to earthquake-induced lateral spread movement because the shears are traceable into and along the 
bedding of the stratum that liquefied. At these sites, gravity-induced (nonearthquake) slumping was precluded by low slope angles and high frictional strength of the sand materials. Only rarely is an exposure sufficiently deep to show that the shear goes into a stratum that liquefied, and thus an earthquake origin cannot be confidently assigned at all sites. However, we are of the opinion that these reverse shears along crater edges are strongly indicative of an earthquake origin, even where they have formed on gently sloping ground (less than 2 percent) as much as $5 \mathrm{~m}$ below the beach crest. Confidence in Interpretation of Origin

Features at all sites shown on Figure 1 are interpreted to be of earthquake origin, although the confidence level differs for various sites. Sites where we have greatest confidence are those where the following features occur: (1) craters have formed on topographically high beach ridge crests; (2) ground oscillation shears have formed in opposite directions; (3) lateral spreads have formed which could not be gravity-induced, and have shears traceable into a liquefied stratum; or (4), shattered ground is cut by numerous sand-filled dikes in settings where high artesian pressures could not have been involved. Sites of highest confidence include the following: HAR, BLUF, BR, AR, HW, ARP, RRR, CH, FM, WV, MCL, SAN, OL, and SOPO.

All other sites on Figure 1 are filled craters that are more than several meters below the crests of beach ridges, causing the confidence level to be lower. Some craters at site MYRB have reverse shears, however, which makes an earthquake origin very probable.

Elimination of all sites from Figure 1 except those in which we have highest confidence does not affect our interpretation of Holocene seismic activity (discussed below). 


\section{AGES OF CRATERS}

Craters are generally the only features for which radiocarbon ages related to earthquake ages can be generated, because other liquefactionrelated features are not found in association with preserved organic matter. Three methods have been used to bracket the times of crater formation (Weems and others, 1986): (1) radiocarbon ages of woody material (tree limbs or pine bark) that fell into the open crater soon after crater formation; (2) dating of roots sheared off at the edge of the crater (pre-dating crater crater formation), and dating of roots that grew into the stratified fill portion of the crater (post-dating crater formation) and (3) dating of clasts of Bh material that fell into the graded fill zone of the crater. The first method yields a highly accurate age for the time of earthquake occurrence, whereas the other two yield a broad range of possible ages. Sufficient data have been collected at site HW (near Charleston) to show that at least three pre-1886 earthquakes produced sand blows within within the past 7200 years. Radiocarbon dating of pine bark in a crater at site ARP (also near Charleston) independently verifies the middle of these three events. The only definitive statement about earthquake recurrence that can presently be made is that, near Charleston, there have been at least four sand-blow-producing ( $m_{b}$ probably >5.5) earthquakes within the past 7200 years (including the 1886 event). Highly accurate ages of crater formation have been obtained from sites far from Charleston, however, that differ from ages near Charleston, thereby suggesting that the craters far from Charleston emanated from epicentral regions far from Charleston. Insufficient radiocarbon ages have been determined from liquefaction features throughout the Carolina coastal region to define epicentral regions of separate earthquakes. At many sites far from Charleston, there are at least two generations of craters that are long 
separated in time of formation.

\section{HOLOCENE EARTHQUAKE SHAKING}

\section{Methodology}

Measurement of the size and number of craters at each site shown on Figure 1 provides a means to estimate the relative severity of shaking that has affected the coastal region during the Holocene. The methodology for estimating shaking intensity is based on the premise that the number and size of liquefaction features is greatest where earthquake shaking is strongest, for a fixed geologic setting and liquefaction susceptibility. The condition of a fixed yeologic setting is met almost ideally. Most sites shown in the unshaded area of Figure 1 are in Pleistocene beach deposits (units Q2 and Q3 of McCartan and others, 1984) of approximately the same thickness lying on Tertiary marl that is rock-like with respect to transmission of seismic energy; such sites provide a narrow range of geologic settings. Thus, bedrock shaking, which has been amplified to produce liquefaction in the near-surface sediments, has almost certainly been amplified comparably at many places throughout the coastal region.

The condition of a uniform liquefaction susceptibility is also almost certainly satisfied at the widely scattered sites on Figure 1. Source-stratum sands typically are loose (based on limited Standard Penetration data and numerous observations of ease of augering) and have about the same thickness. Moreover, the thickness and properties of non-liquefiable sediments overlying the source stratum lie within a narrow range. It is also a certainty that reoccurrences of liquefaction does not greatly diminish the ability to produce numerous large craters in the loose sands that are typical of the Carolina coastal reyion. (This is verified by the observation that, at 
site HW, there are large numbers of large craters that formed in each of at least three generations of Holocene earthquakes, with each generation widely spaced in time.) Thus, at sites in beach deposits on Figure 1, liquefaction susceptibility is generally high and has not have been greatly reduced by a previous occurrence of liquefaction.

Depth to the water table, the other major variable, is uniformly very shallow and has been shallow throughout the Holocene as evidenced by the depth of the Bh horizon (see Fig. 3). The maximum depth of the seasonal water table during the Holocene is marked very nearly by the base of the Bh horizon, which is the zone of accumulation of organic matter and forms above the limit of vertical infiltration of water. Throughout the coastal region, the base of the $\mathrm{Bh}$ (generally 0.6 to $1 \mathrm{~m}$ below land surface) is nearly coincident with the present-day water table. Radiocarbon ages from the basal Bh horizon are 5 to 10 thousand years at site HW (Weems and others, 1986, p. 7). Because these ages are mean residence times of organic matter in a dynamic system with continuing vertical infiltration of younger organic matter, some of the organic matter has been there even longer. Furthermore, below the base of the Bh horizon, these soils lack measureable ( 0.1 percent) organic carbon and any evidence of prior oxidization or illuviation that indicates vadose conditions have ever extended below the present base of the Bh horizon. In summary, it can be concluded that the water table has been very shallow throughout the Holocene over wide areas of the Carolina Coastal Plain

\section{Shaking Intensity}

Figure 4 shows the relative number of pre-1886 craters and the ranges of crater diameters for selected areas along the coast. Four clases of crater diameters are shown: sma11, medium, large, and huge. These diameters are the maximum widths exposed in the ditch walls. The relative number is the measure 
of the number of craters per unit area found in the setting most susceptible to earthquake-induced liquefaction. The relative numbers constitute a semiquantitative index of crater density based on our exploration of numerous drainage-ditch networks throughout the region. A relative number of 1000 has been arbitrarily assigned to the area encompassed by the 1886 meizoseismal zone. Based on this, a value of about 10 is appropriate for the area north of the Santee River; this is equivalent to stating that there are approximately one percent as many craters north of the Santee River as in the 1886 meizoseismal zone.

Both the relative number and crater diameter are greatest within the 1886 meizoseismal zone. Both decrease with distance from the 1886 meizoseismal zone, although the shape of their associative curves remains about the same. The relationships are consistent with the conclusion that the distribution represents a variation in exposure to strong earthquake shaking. Based on this line of reasoning, we conclude that pre-1886 Holocene shaking has been strongest in the approximate area of the 1886 meizoseismal zone. North of the Santee River, shaking has been much weaker. Intermediate shaking has taken place between Charleston and the Santee River, and also between Beaufort and the Savannah River.

Confidence in this interpretation is moderate to high for the area between Charleston and Wilmington, because of the hundreds of kilometers of ditches we searched. Our confidence is high for the 1886 meizoseismal zone, and moderate to high for the area between Beaufort and the Savannah River. Our confidence is not nearly as high for the area between the Beaufort and the Edisto River, and in the area southeast of the 1886 meizoseismal zone; this lower confidence is caused by the limited number of ditches and pits available for inspection. 
Whether or not the pre-1886 Holocene shaking in the 1886 meizoseismal zone is associable with earthquakes stronger than the 1886 event can be resolved only by further radiocarbon ages for craters at sites far beyond the 1886 meizoseismal zone.

\section{CONCLUSIONS}

1. At least three prehistoric liquefaction-inducing earthquakes have taken place within the past 7200 years, near Charleston. Different ages of craters have been obtained far from Charleston, suggesting more epicenters exist far from Charleston.

2. Preliminary data indicate that Holocene earthquake shaking has been stronger near Charleston than elsewhere along the coast of South Carolina and the coast of southeastern North Carolina.

\section{ACKNOWLEDGEMENTS}

This study was acomplished only with the generous assistance of many people and many organizations. The field-intensive nature of the study required permission to work at sites scattered throughout South Carolina. Numerous people who assisted are not listed below. We especially thank Messrs. Don McConaughy and Jack Lacy, Westvaco Corporation; Mr. James Ralston, International Paper Company; Messrs. J. G. McGavin II, and M. B. Walden, Union Camp Corporation. We also thank Prof. Joyce Bagwell and Baptist College of Charleston for generously permitting us to use their facilities.

The research was supported by the U.S. Nuclear Regulatory Commission under Agreement Number RES-82-001. 


\section{REFERENCES}

Bollinger, G.A., 1977, Reinterpretation of the intensity data for the 1886 Charleston, South Carolina, earthquake, in Rankin, D.W., ed., Studies related to the Charleston, South Carolina, earthquake of 1886-A preliminary report: U.S. Geological Survey Professional Paper 1028, p. 17-32.

Dewey, J.W., 1985, A review of recent research on the seismotectonics of the Southeastern seaboard and an evaluation of hypotheses on the source of the 1886 Charleston, South Carolina, earthquake: U.S. Nuclear Regulatory Commission, Washington, D.C., NUREG/CR-4339, 44 p.

Dutton, C.E., 1889, The Charleston earthquake of August 31, 1886:

U.S. Geological Survey Ninth Annual Report 1887-88, p. 203-528. Gohn, G.S., Weems, R.E., Obermeier, S.F., and Gelinas, R.L., 1984, Field studies of earthquake-induced liquefaction-flowage features in the Charleston, South Carolina area: preliminary report: U.S. Geological Survey Open-File Report 84-670, 26 p.

Hayes and Gori, eds., 1983, Proceedings of Conference XX, A workshop on "The 1886 Charleston, South Carolina, earthquake and its implications for today": U.S. Geological Survey Open-File Report 83-843, 502 p. McCartan, L., Lemon, E.M., Jr., and Weems, R.E., 1984, Geologic map of the area between Charleston and Orangeburg, South Carolina: U.S. Geological Survey Miscellaneous Investigations Map I-1472, scale 1:250,000. Nuttli, 0.W., 1983, 1886 Charleston, South Carolina, earthquake revisited, in Hays, W.W., and Gori, P.L., Proceedings of Conference XX, A workshop on "The 1886 Charleston, South Carolina, earthquake and its implications for today": U.S. Geological Survey Open-File Report 83-843, p. 44-50. Obermeier, S.F., Gohn, G.S., Weems, R.E., Gelinas, R.L., and Rubin, M., 1985, 
Geologic evidence for recurrent moderate to large earthquakes near Charleston, South Carolina: Science, v. 227, p. 408-411.

Obermeier, S.F., Jacobson, R.B., Powars, D.S., Weems, R.E., Hal lbick, D.C., Gohn, G.S., and Markewich, H.W., 1986, Holocene and late Pleistocene(?) earthquake-induced sandblows in coastal South Carolina: Proceedings of the third U.S. National conference on earthquake engineering, Earthquake Engineering Research Institute, v. 1, p. 197-208.

Peters, K.E., and Herrmann, R.B., compilers and eds., 1986, First-hand observations of the Charleston earthquake of August 31, 1886, and other earthquake materials: South Carolina Geological Survey, Bulletin 41, $116 \mathrm{p}$.

Science News, 1986, A century after the Charleston earthquake: v. 129, no. 17, Apri1 26, 1986, p. 263. Szabo, B.J., 1985, Uranium-series dating of fossil corals from marine sediments of southeastern United States Coastal Plain: Geological Society of America Bulletin, v. 96, p. 398-406. Weems, R.E., Obermeier, S. F., Pavich, M.J., Gohn, G.S., Rubin, M., Phipps, R.L., and Jacobson, R.B., 1986, Evidence for three moderate to large prehistoric Holocene earthquakes near Charleston, South Carolina: Proceedings of the third U.S. National conference on earthquake engineering, Earthquake Engineering Research Institute, v. 1, p. 197-208. 


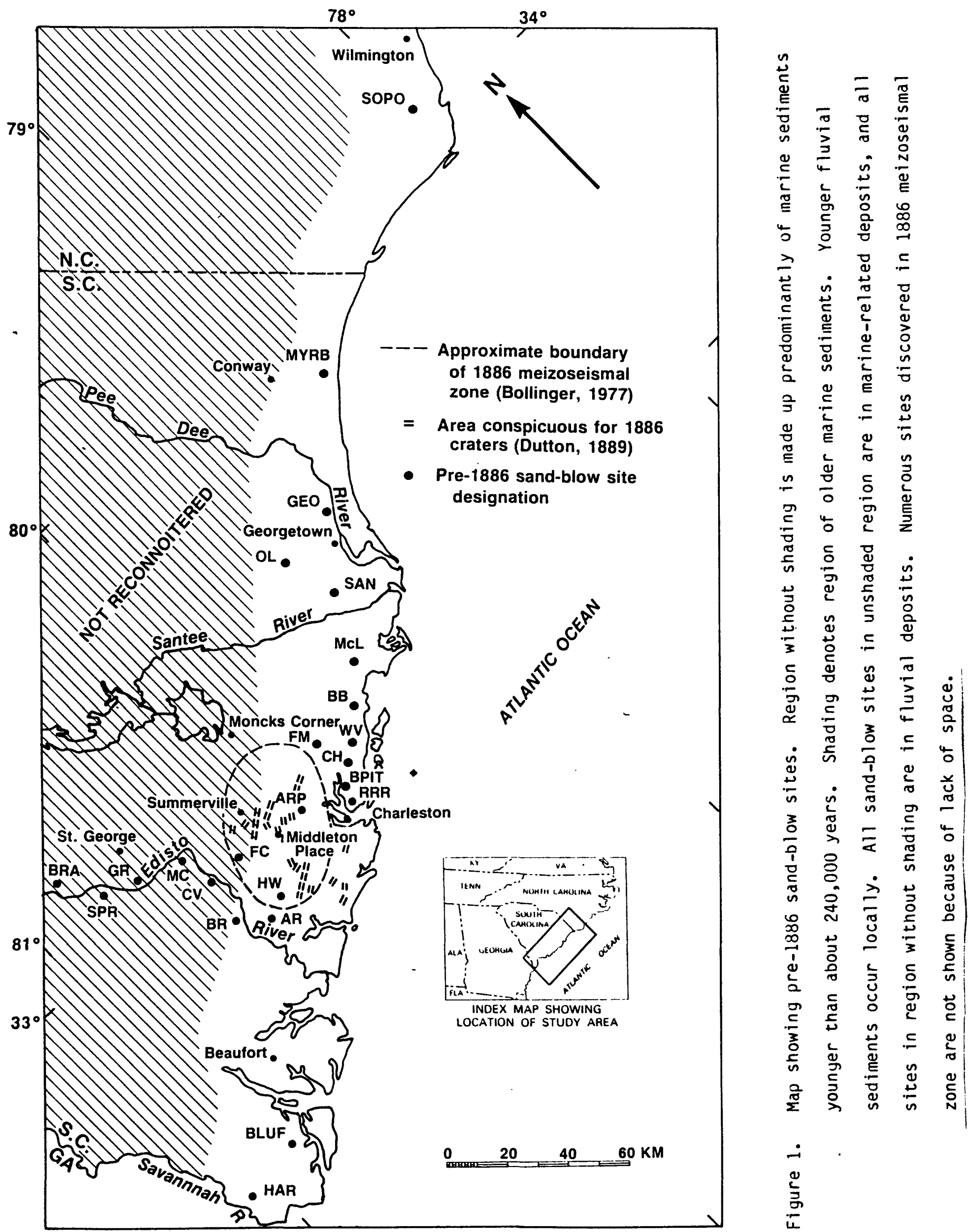




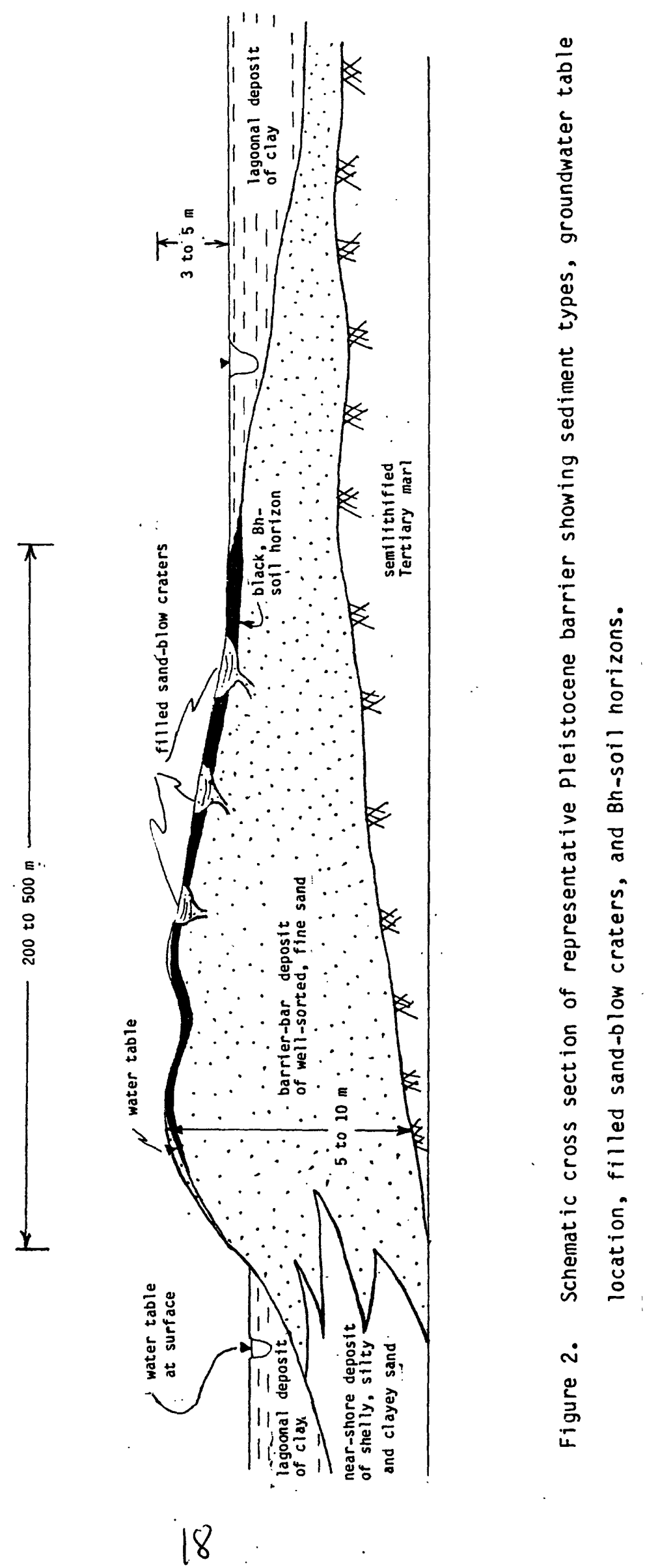




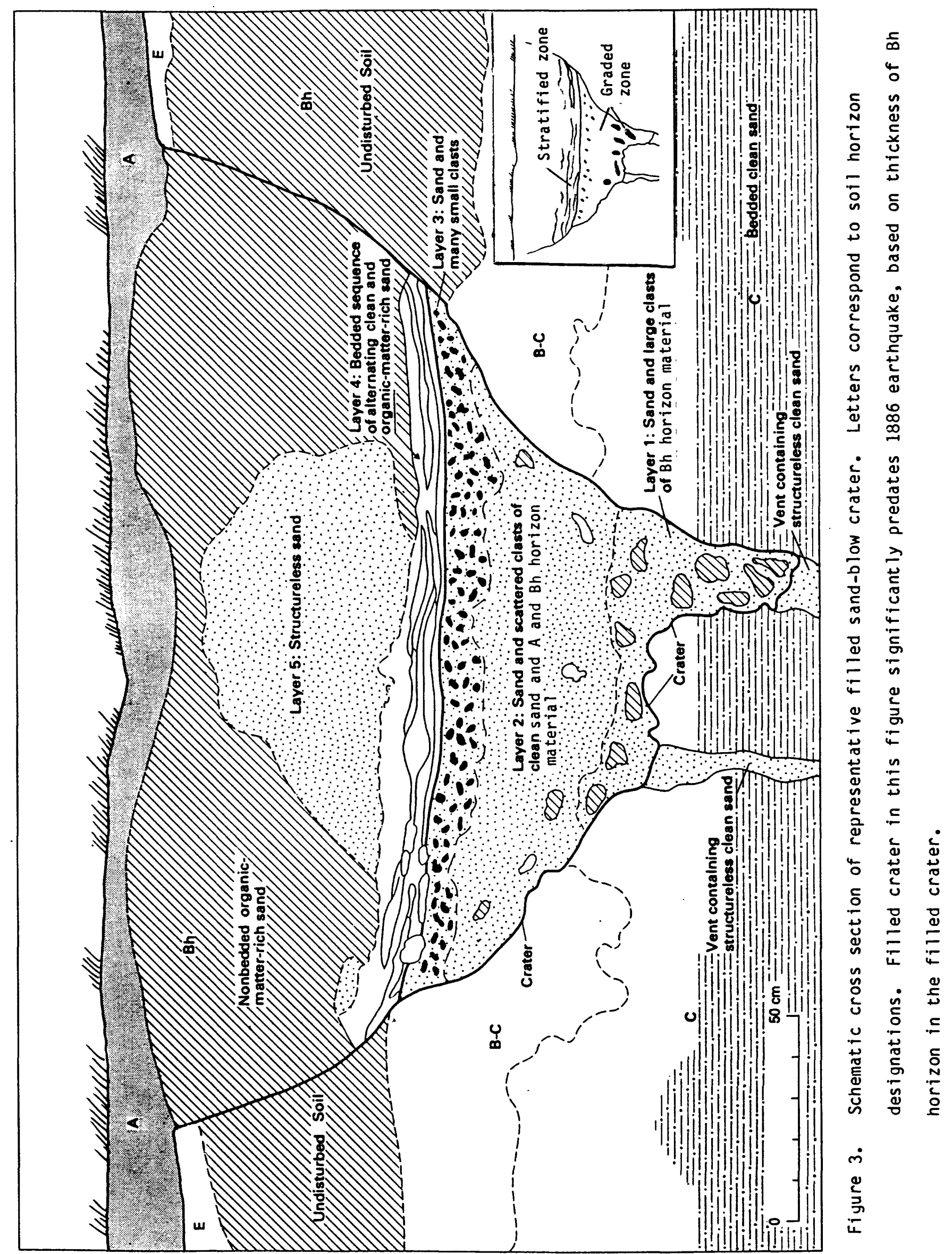




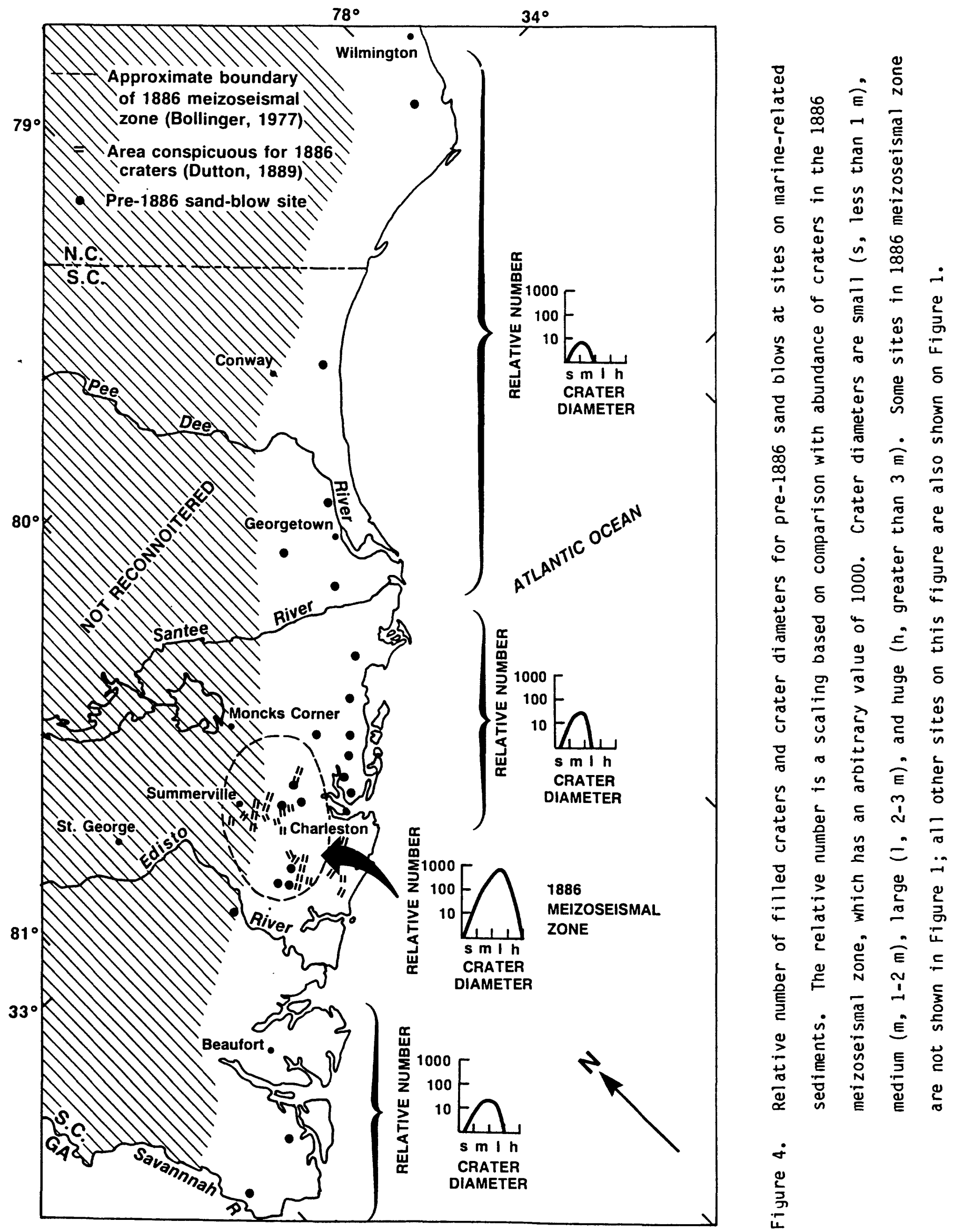

